\title{
STRUCTURAL ADAPTATION OF THE LEAF TO XERO- AND HALOFACTORS IN SOME SPECIES OF THE GENUS CLIMACOPTERA BOTSCH.
}

\author{
G. M. Duschanova \\ Institute of Gene Pool of Plants and Animals, Academy of Sciences, 232 Bagishamol Str. \\ Tashkent 100053, Republic of Uzbekistan; E-mail: guljon.duschanova@mail.ru
}

(Received 21 April, 2014; Accepted 25 July, 2014)

\begin{abstract}
Xeromorphism and halomorphism were investigated in five species of Chenopodiaceae grown under natural growth conditions in the saline soil in Mirzachul (Uzbekistan, Province Sirdarya) and Kyzylkum (Uzbekistan, Province Buhora, Navoiy, Karakalpakstan, Province Miskin). The structure of leaf epidermis and mesophyll was analysed. The adaptation mechanism of succulent species with Kranz anatomy to xero- and halofactors was identified. In leaves two types of mesophyll cells were found: on the basis there is a Kranzventro-dorsal structure. In the middle part and the tip, however, the structure is close to Kranz-centric (Salsoloid type), but differs from species of the genus Salsola by not having dense chlorenchyma at the adaxial side and between peripheral conductive bundles and a Kranz-facing it is located 1-3 numbers small water-bearing cells. At species of genus Salsola conductive bundles adjoin to Kranz-facing cells. We consider this structure as specific of Climacoptera and term it, therefore, Climacoptera type. High analogy coefficients of the same section species under different growing conditions were found using cluster analysis.
\end{abstract}

Key words: adaptation, anatomy, Climacoptera, halophyte, Kyzylkum, Mirzachul

\section{INTRODUCTION}

Leaves of Climacoptera Botsch. (Chenopodiaceae) species are objects of study by anatomists and taxonomists of different countries for revealing its adaptive and diagnostic features. Specification of alliance and the evolutionary level of this taxon are still open questions (Kadereit et al. 2003).

Lyubimov et al. (1986) described the structure of C. crassa (M. Bieb.) Botsch. leaves from central Karakum (desert) based on the photosynthesis type. They noted the disconnection of chlorenchyma layers placed on the 
adaxial side of leaves. The authors emphasised that succulents with $\mathrm{C}_{4}-\mathrm{CAM}$ type photosynthesis produce 20 times more proteins than the succulents with $\mathrm{C}_{3}$ photosynthesis, and C. crassa species belongs to it.

P'yankov et al. (1992) studied the leave structure of 22 Chenopodiaceae species in Central Asia in connection with $\mathrm{C}_{4}$ and $\mathrm{C}_{3}$ types of fixing of $\mathrm{CO}_{2}$. The leave structure of Climacoptera transoxana (Iljin) Botsch. was described as Salsoloid (Carolin et al. 1975) and a primitive aspartat metabolism of $\mathrm{C}_{4}$-type of photosynthesis was reported. Kadereit et al. (2003) characterised the type of mesophyll cells of Climacoptera as an independent Climacoptera type, different from Salsola species by not having contact of peripheral conducting bundles with a Kranz-lining, but were separated by hydrophoric cells.

Akhani and Ghasemkhani (2007) described C. brachiata (Pall.) Botsch. and C. turcomanica (Litv.) Botsch. leaves due to the type of photosynthesis. Lowering of young leaves, Salsoloid type anatomy, and monostichous epidermis were noted. The Kranz structure is interrupted in the primary rib area on the adaxial side.

Butnik et al. (2009) described the structure of C. lanata (Pall.) Botsch. leaves, specifying the mesophyll type as Kranz-centric, but different from Salsola species. The chlorenchyma occupies a very small area in the leaves compared with the hydrophoric parenchyma. The parenchyma accumulates abundant druses and preserves moisture during the vegetation period.

The Kranz structure type of mesophyll provides a transition to a more effective level of carbon assimilation by the $\mathrm{C}_{4}$-CAM-type of photosynthesis with the aspartate type of metabolism (Atakhanov and Bil 1990, Lyubimov et al. 1986, P'yankov et al. 1998, 2000). Voznesenskaya et al. (1999) showed the absence of CAM photosynthesis, despite the presence of chloroplasts in the hydrophoric cells of some Climacoptera species.

Previous studies of Climacoptera leaves focused on determining the type of mesophyll cells and the ecological type of plants. Our research focused on the quantitative characterisation of the leaf structure of five species of Climacoptera in connection with their ecological properties and different evolutionary position in the genus system.

It is well established now that the structure of xerophyte leaves cannot be described by one single type. Instead, four structural and ecological leafgroups with different and often contradictory features were identified in the Chenopodiaceae genus (Butnik 1995, Gamalei and Shirevdamba 1988).

The classical characteristics of xerophytes epidermis are defined as follows: pubescence, thick cuticle and wax scurf, thickening of the outer wall of cells, small-celled structure, and submerged stomata (Korovin 1958, Oppenheimer 1960, Seddon 1974, Stocker 1960). Leaf epidermis of succulent xerophytes, including the Chenopodiaceae genus, is often large-cellular, hav- 
ing thick or thin cuticula with water-storing function (Butnik and Timchenko 1987, Sundberg 1986).

The important role of the epidermis bases on its multifunctionality. Processes like respiration, photosynthesis, or transpiration depend on transport via the epidermis. This tissue also provides protection under adverse environmental conditions.

\section{MATERIALS AND METHODS}

Leaves of five Climacoptera species from three sections were examined: 1. Section Ulotricha Pratov. - Climacoptera ferganica (Drob.) Botsch. is an annual plant, euhalophyte, grows in solonchaks (saline soils), takyrs (dry-type playa) and saline sands. Geographical range: Iran, Afghanistan, Central Asia, and Dzungaria. 2. Section Amblyostegia Pratov. - Climacoptera intricata (Iljin) Botsch. is an annual plant, euhalophyte, grows in solonchaks (saline soils). Endemic to Central Asia. - Climacoptera aralensis (Iljin) Botsch. is an annual plant, euhalophyte, grows in solonchaks, saline sands. Endemic to Central Asia. 3. Section Climacoptera Pratov. - Climacoptera lanata (Pall.) Botsch. is an annual plant, euhalophyte. The species with a wider area: Turkey, Iran, Afghanistan, Pakistan, northeastern area of Russia, Central Asia, Dzungaria and therefore more diverse ecology, solonchaks (saline soils), pit-run fines-gravelly soils, saline sands. - Climacoptera longistylosa (Iljin) Botsch. is an annual plant, grows on saline soils. Natural habitat: Afghanistan, Central Asia and Kazakhstan.

C. intricata and C. longistylosa grow in Mirzachul (Uzbekistan, Province Sirdarya) in compacted less saline soils, C. ferganica, C. lanata and C. aralensis grow in southwestern Kyzylkum (Uzbekistan, Province Buhora, Navoiy and Karakalpakstan, Province Miskin) on less compacted sandy loam, but more saline soils.

The established leaves from the middle layer of annual shoots in the beginning of flowering period were examined. Morphological description and phenological observations were carried out in natural habitats. Succulent leaves were fixed in $70 \%$ ethanol. The type of mesophyll was defined on cross sections through the middle of the leaves. Epidermis was studied in paradermal preparations and cross sections. The sections were made by razor, imbued with methylene blue, and were sealed in glycerol-gelatine. The form and outlines of basal epidermal cells were described by Zakharevich's methods (1954). The measurements were carried out according to the standard method (Barykina and Chubatova 2005). The drawings of preparations were made with a drawing apparatus RA-6 under the microscope MBI-3. The measurements were carried out in thirtyfold replicates, calculated in average value, measurement errors and significance by Dospekhov's formula (1979). Cluster 
analysis was performed according to the Past program based on similarity coefficient of Jaccard (Schmidt 1984).

\section{RESULTS AND DISCUSSION}

Species of the genus Climacoptera are typical leaf succulents. Adaptive features of a succulent group are the presence of a specialised water-storage tissue, with water- and salt-retaining functions by other tissues of leaves, including the epidermis.

Analysis of quantitative characteristics of leaves showed the typical signs of Climacoptera Botsch species. C. longistylosa and C. intricata had the largest leaves sizes, $C$. ferganica, $C$. lanata and $C$. aralensis had the smaller ones. The leaves are downy with three types of trichomes: long three- or eight-cellular single-row trichomes with a wide base, deciduous; short one- or two-cellular with a narrow base (3 types), numerous long thin thread-like trichomes of one type (C. intricata). The leaves of $C$. ferganica are the least downy (Table 1$)$.

Table 1

Quantitative measures of trichomes and stomata in leaves of Climacoptera species $(n=30)$

\begin{tabular}{|c|c|c|c|c|c|}
\hline \multirow[t]{2}{*}{ Indicator } & \multicolumn{5}{|c|}{ Species } \\
\hline & C. ferganica & C. lanata & C. intricata & $\begin{array}{l}\text { C. longi- } \\
\text { stylosa }\end{array}$ & C. aralensis \\
\hline $\begin{array}{l}\text { Number of tri- } \\
\text { chomes per } 1 \mathrm{~mm}^{2}\end{array}$ & $51.3 \pm 2.0$ & $272.8 \pm 5.8$ & $280.7 \pm 7.0$ & $210.4 \pm 5.0$ & $63.2 \pm 2.3$ \\
\hline \multicolumn{6}{|c|}{ Length of trichomes $(\mu \mathrm{m})$} \\
\hline one-cellular & $222.3 \pm 12.0$ & $225.4 \pm 4.3$ & $311.0 \pm 4.0$ & $236.7 \pm 7.7$ & $200.5 \pm 4.5$ \\
\hline two-cellular & $403.9 \pm 16.0$ & $452.7 \pm 17.0$ & $1002.6 \pm 34.0$ & $325.2 \pm 4.2$ & $305.8 \pm 4.2$ \\
\hline three-cellular & $846.4 \pm 5.4$ & $1159.1 \pm 13.0$ & none & $622.7 \pm 7.3$ & none \\
\hline four-cellular & $1101.0 \pm 10.0$ & none & none & none & none \\
\hline \multicolumn{6}{|l|}{ d-trichome base } \\
\hline one- or two-cellular & $26.3 \pm 0.3$ & $14.0 \pm 0.3$ & $10.0 \pm 0.2$ & $13.3 \pm 0.9$ & $11.1 \pm 0.2$ \\
\hline $\begin{array}{l}\text { three- or four- } \\
\text { cellular }\end{array}$ & $54.8 \pm 0.2$ & $47.0 \pm 1.4$ & none & $56.8 \pm 1.2$ & none \\
\hline $\begin{array}{l}\text { Number of stomata } \\
\text { per } 1 \mathrm{~mm}^{2}\end{array}$ & $68.2 \pm 2.0$ & $67.0 \pm 2.0$ & $52.5 \pm 2.0$ & $61.2 \pm 2.0$ & $85.6 \pm 2.0$ \\
\hline \multicolumn{6}{|l|}{ Stomata } \\
\hline length, $\mu \mathrm{m}$ & $27.8 \pm 0.2$ & $22.8 \pm 0.2$ & $26.6 \pm 0.3$ & $27.7 \pm 0.2$ & $31.8 \pm 0.3$ \\
\hline width, $\mu \mathrm{m}$ & $22.8 \pm 0.2$ & $21.8 \pm 0.1$ & $26.5 \pm 0.1$ & $26.3 \pm 0.2$ & $22.4 \pm 0.2$ \\
\hline submergence & $18.3 \pm 0.5$ & none & none & $14.8 \pm 0.6$ & $20.7 \pm 0.4$ \\
\hline
\end{tabular}



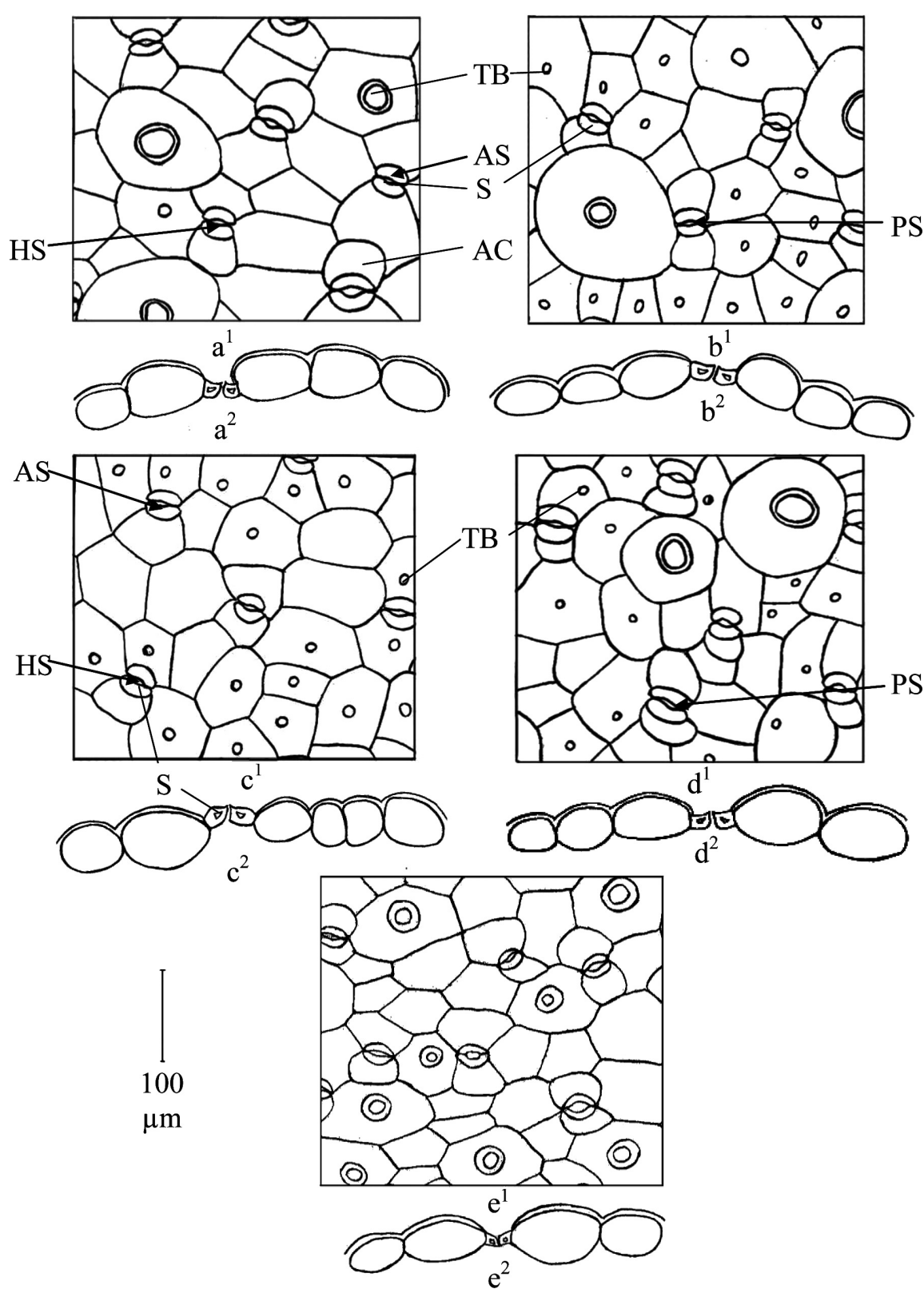

Fig. 1. Leaf epidermis structure of Climacoptera species: $\mathrm{a}^{1}-\mathrm{a}^{2}=\mathrm{C}$. ferganica; $\mathrm{b}^{1}-\mathrm{b}^{2}=C$. lanata; $\mathrm{c}^{1}-\mathrm{c}^{2}=$ C. intricata; $\mathrm{d}^{1}-\mathrm{d}^{2}=$ C. longistylosa $; \mathrm{e}^{1}-\mathrm{e}^{2}=$ C. aralensis. $\mathrm{a}^{1}-\mathrm{e}^{1}$ : paradermal sections; $\mathrm{a}^{2}-$ $\mathrm{e}^{2}$ : transverse sections; $\mathrm{a}^{2}-\mathrm{d}^{2}-\mathrm{e}^{2}$ : submerged stoma; $\mathrm{b}^{2}-\mathrm{c}^{2}$ : non-submerged stoma. Abbreviation: $\mathrm{AC}=$ accessory cell; $\mathrm{AS}=$ anomocytic stoma; $\mathrm{HS}=$ hemiparacytic stoma; $\mathrm{PS}$ = paracytic stoma; $\mathrm{S}=$ stoma; $\mathrm{TB}=$ trichome base 
Table 2

Quantitative measures of leaves of Climacoptera species $(\mathrm{n}=30)$

\begin{tabular}{|c|c|c|c|c|c|}
\hline \multirow[t]{2}{*}{ Indicator } & \multicolumn{5}{|c|}{ Species } \\
\hline & $\begin{array}{l}\text { C. fer- } \\
\text { ganica }\end{array}$ & C. lanata & C. intricata & $\begin{array}{l}\text { C. longi- } \\
\text { stylosa }\end{array}$ & C. aralensis \\
\hline \multicolumn{6}{|c|}{ Leaf } \\
\hline length, $\mathrm{cm}$ & $19.8 \pm 0.6$ & $21.8 \pm 0.8$ & $30.0 \pm 0.8$ & $31.6 \pm 0.5$ & $17.4 \pm 0.3$ \\
\hline width, $\mathrm{mm}$ & $1.8 \pm 0.04$ & $2.2 \pm 0.07$ & $1.9 \pm 0.04$ & $2.4 \pm 0.7$ & $1.6 \pm 0.04$ \\
\hline thickness, $\mathrm{mm}$ & $1.28 \pm 0.01$ & $1.46 \pm 0.02$ & $1.43 \pm 0.01$ & $1.33 \pm 0.01$ & $1.1 \pm 0.01$ \\
\hline \multicolumn{6}{|c|}{ Epidermis } \\
\hline height, $\mu \mathrm{m}$ & $37.0 \pm 0.3$ & $32.1 \pm 0.3$ & $45.1 \pm 0.4$ & $31.4 \pm 0.3$ & $40.0 \pm 0.5$ \\
\hline thickness of outerwall, $\mu \mathrm{m}$ & $4.3 \pm 0.1$ & $3.7 \pm 0.1$ & $7.5 \pm 0.1$ & $4.5 \pm 0.1$ & $5.8 \pm 0.1$ \\
\hline area of cell, $\mu \mathrm{m}^{2}$ & $2908 \pm 38.5$ & $2155 \pm 19.1$ & $3610 \pm 52.4$ & $3621 \pm 39.7$ & $2890.6 \pm 50.3$ \\
\hline \multicolumn{6}{|c|}{ Palisade parenchyma } \\
\hline height, $\mu \mathrm{m}$ & $49.2 \pm 0.4$ & $56.3 \pm 0.6$ & $50.0 \pm 0.3$ & $65.4 \pm 0.4$ & $49.4 \pm 0.3$ \\
\hline width, $\mu \mathrm{m}$ & $14.0 \pm 0.2$ & $12.0 \pm 0.2$ & $13.3 \pm 0.2$ & $15.1 \pm 0.1$ & $13.6 \pm 0.2$ \\
\hline index of palisade & $3.5 \pm 0.06$ & $4.7 \pm 0.08$ & $3.8 \pm 0.06$ & $4.3 \pm 0.04$ & $3.7 \pm 0.1$ \\
\hline \multicolumn{6}{|c|}{ Waterbearing cells, $\mu \mathrm{m}$} \\
\hline layer thickness & $1197.4 \pm 4.1$ & $180.9 \pm 7.8$ & $1316.2 \pm 8.2$ & $1087.7 \pm 7.3$ & $1245.2 \pm 7.3$ \\
\hline$\%$ of d-leaf & 95 & 91 & 89 & 88 & 91 \\
\hline d-cell & $189.8 \pm 4.3$ & $138.5 \pm 3.9$ & $200.3 \pm 5.3$ & $218.8 \pm 3.2$ & $332.2 \pm 2.7$ \\
\hline number of rows & $6-7$ & $7-8$ & $6-7$ & $5-6$ & 4 \\
\hline Kranz-lining, height, $\mu \mathrm{m}$ & $18.3 \pm 0.2$ & $16.0 \pm 0.1$ & $28.0 \pm 0.3$ & $19.3 \pm 0.4$ & $19.1 \pm 0.1$ \\
\hline $\begin{array}{l}\text { Number of vascular } \\
\text { bundles }\end{array}$ & $25.3 \pm 0.3$ & $23.2 \pm 0.2$ & $23.4 \pm 3.0$ & $23.7 \pm 0.3$ & $20.6 \pm 0.4$ \\
\hline $\begin{array}{l}\text { Number of vessels in the } \\
\text { main vascular bundle }\end{array}$ & $13.7 \pm 0.4$ & $15.7 \pm 0.3$ & $17.5 \pm 0.3$ & $23.8 \pm 0.4$ & $23.4 \pm 0.4$ \\
\hline Diameter of vessels, $\mu \mathrm{m}$ & $9.0 \pm 0.2$ & $9.1 \pm 0.2$ & $15.8 \pm 0.3$ & $9.9 \pm 0.2$ & $11.3 \pm 0.3$ \\
\hline
\end{tabular}

Epidermis is monostichous (single row), consisting of large round isodiametrical cells with straight-line contours and a thick outer wall. The observations of Inamdar et al. (1977), and Butnik and Timchenko (1987) were confirmed about the presence of different types of stomata on a single leaf. The following three types were reported for Climacoptera species: anomocytic (except for C. longistylosa, C. aralensis), hemiparacytic and paracytic (Fig. 2).

The paracytic type of stomata prevails in leaves of $C$. ferganica, C. lanata and C. longistylosa, but the hemiparacytic type of stomata prevails in C. intricata and C. aralensis (Fig. 1, Tables 1-2). 
Epidermis and stomata of succulent species, also in the genus Climacoptera, differ from similar structures at non-succulent typical xerophytes. As a result of halophytism, besides of protective function the leaf epidermis acquired a specific function of water- and salt-accumulation, which is one of the halo-indication features of Climacoptera species.

The following two types of mesophyll were found in leaves: mesophyll is Kranz-ventral-dorsal at the leaf base. In the middle section, it is close to Kranz-centric, but differs from species of the genus Salsola by the disconnection of chlorenchyma on the adaxial side. The conducting bundles are separated from Kranz-lining by hydrophoric cells. Following Kadereit et al. (2003), we also consider this mesophyll as an independent Climacoptera type.

The leaves of all species show the combination of xeromorphic and halomorphic features, but manifested themselves in various combinations. Xeromorphic features are as follows: small vessels in conducting bundles in $C$. ferganica; the high index of palisadity, smaller water-storage cells and Kranzlining, and small vessels in the vascular bundles in C. lanata; high palisade cells in C. longistylosa, as well as a high index of a palisadity, thick downiness with numerous thin trichomes, high epidermal cells with thickened outer walls (C. intricata and $C$. aralensis). Halomorphic features of leaves are also present in all species in different combinations: sparse downiness and a thick

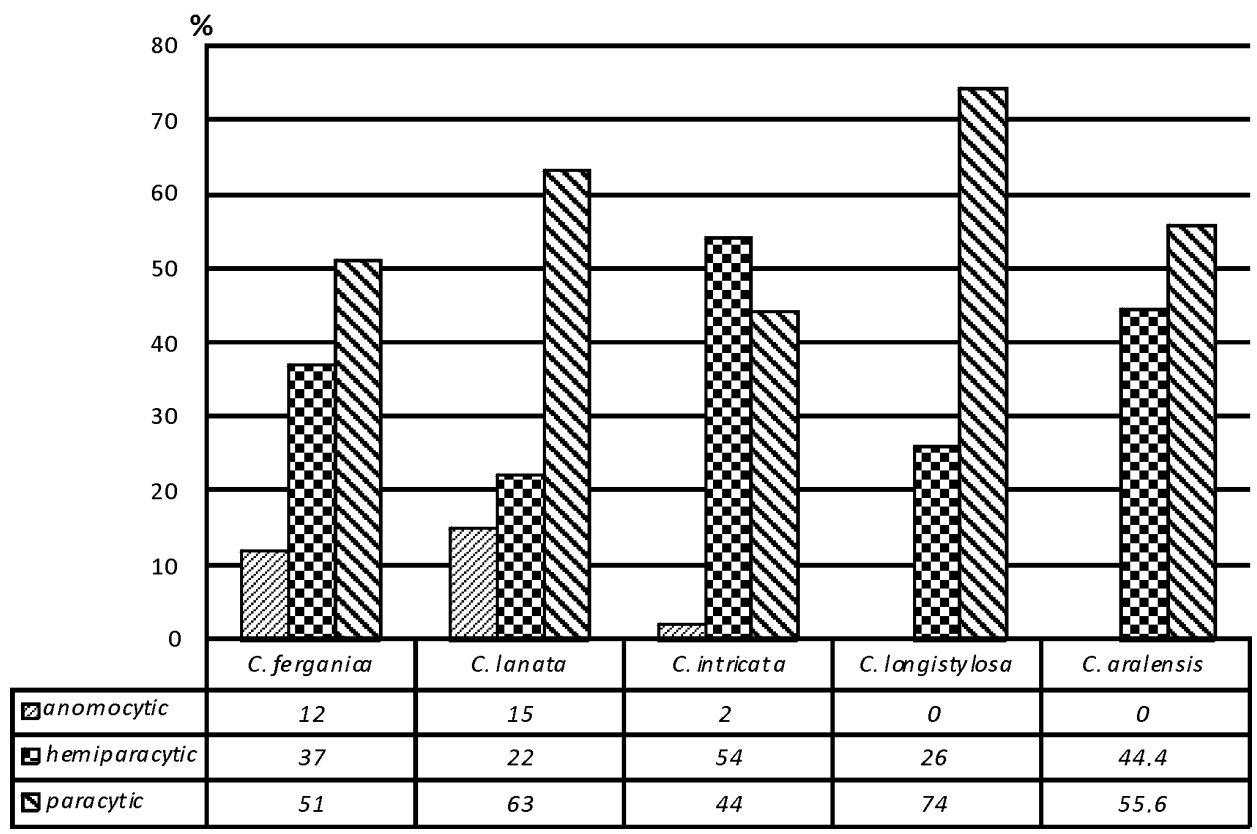

Fig. 2. Ratios of stomata types of Climacoptera species 
Table 3

Jaccard similarity coefficient $(\mathrm{Kj})$ in Climacoptera species by quantitative measurements of leaves

\begin{tabular}{lccccc}
\hline $\begin{array}{l}\text { Indicators and } \\
\text { number of spe- } \\
\text { cies }\end{array}$ & C. ferganica & C. lanata & C. intricata & $\begin{array}{c}\text { C. longisty- } \\
\text { losa }\end{array}$ & C. aralensis \\
\cline { 2 - 6 } 1. C. ferganica & - & 0.19 & 0.12 & 0.14 & 0.17 \\
2. C. lanata & 0.19 & - & 0.14 & 0.24 & 0.10 \\
3. C. intricata & 0.12 & 0.14 & - & 0.17 & 0.23 \\
4. C. longistylosa & 0.14 & 0.24 & 0.17 & - & 0.10 \\
5. C. aralensis & 0.17 & 0.10 & 0.23 & 0.10 & - \\
\hline
\end{tabular}

water-bearing layer were recorded in C. ferganica; large hydrophoric cells, a high Kranz-lining, and large vessels in C. intricata; and large hydrophoric cells, numerous vessels in conducting bundles in C. longistylosa and C. aralensis, respectively (Fig. 3, Table 2).

Overall, leaves of $C$. intricata, C. longistylosa and C. aralensis are characterised by greater succulence and $C$. ferganica and C. lanata are characterised by xeromorphism. We explored the quantitative characteristics of leaves in connection with the ecology of habitat and sectional pertaining. Quantitative indicators of leaf length, the number of stomata per $1 \mathrm{~mm}^{2}$, the ratio of stomata types, the area of epidermal cells, the thickness of the water-storage layer, the height of the cells of Kranz-lining, vessel diameter in the main vascular bundle are similar in species of different sections, but growing up in the same conditions.

Constant genotype signs are: the leaf form (cylindrical), the form of trichomes, type of stomata, type of mesophyll and sequence of an arrangement of cages in leaf structure.

The cluster analysis established that in C. intricata-C. longistylosa from different sections in the same conditions (Mirzachul) the coefficient of similarity of leaf characteristics is 0.17 . C. ferganica, C. lanata, C. aralensis from different sections in the same conditions (Kyzylkum), in C. ferganica-C. lanata is up 0.19 , in $C$. ferganica-C. aralensis made up 0.17 , respectively. C. lanata-C. longistylosa from one section in different environmental conditions is up 0.24 , in C. intricate-C. aralensis from one section in different environmental conditions is up 0.23 (Table 3, Fig. 4).

\section{CONCLUSIONS}

In summary, although the environmental conditions determine the similarity of many indicators of leaves, the genotypic constituent manifests itself more significantly. The greater similarity coefficient of $C$. ferganica-C. lanata, 


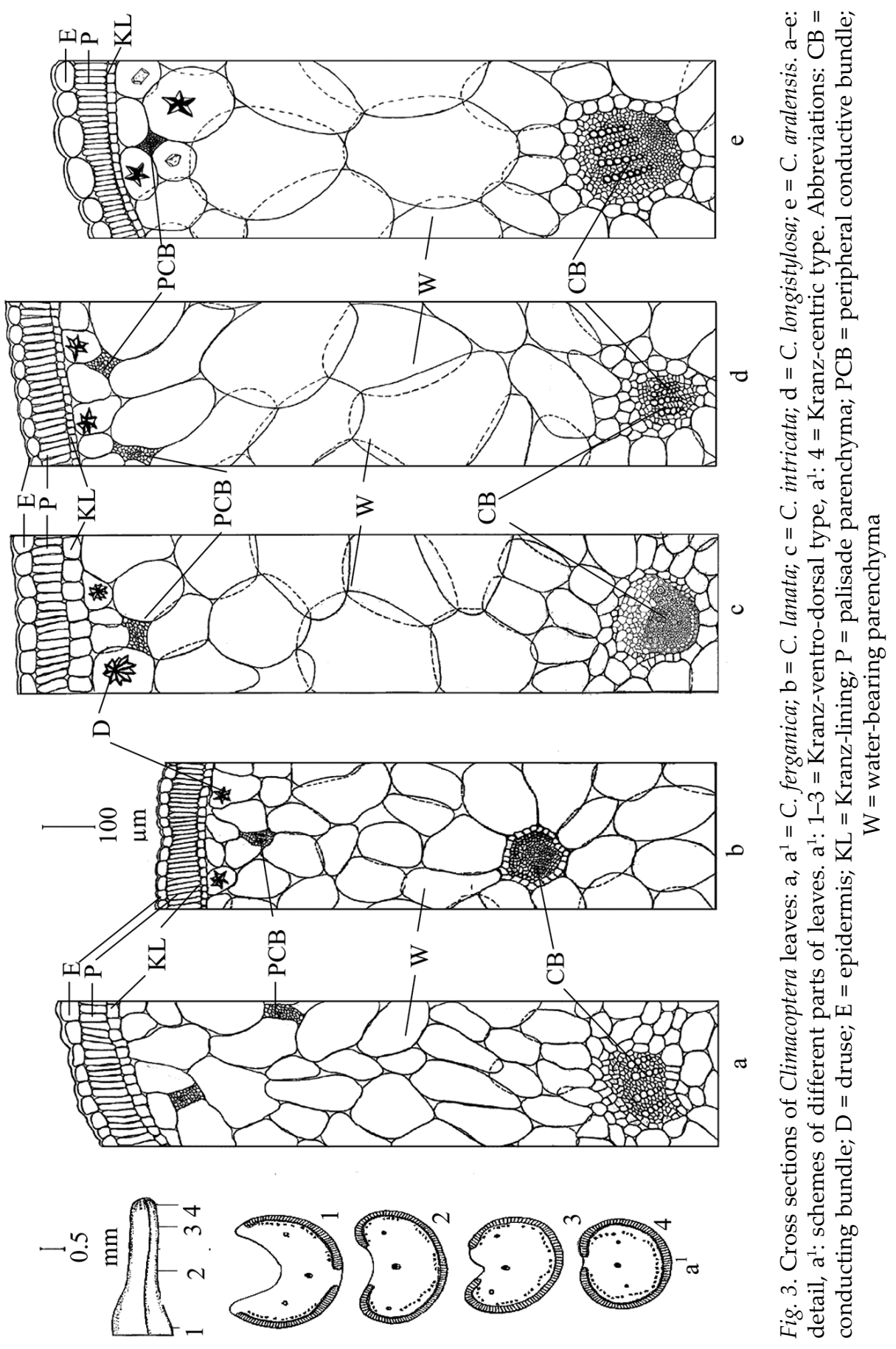




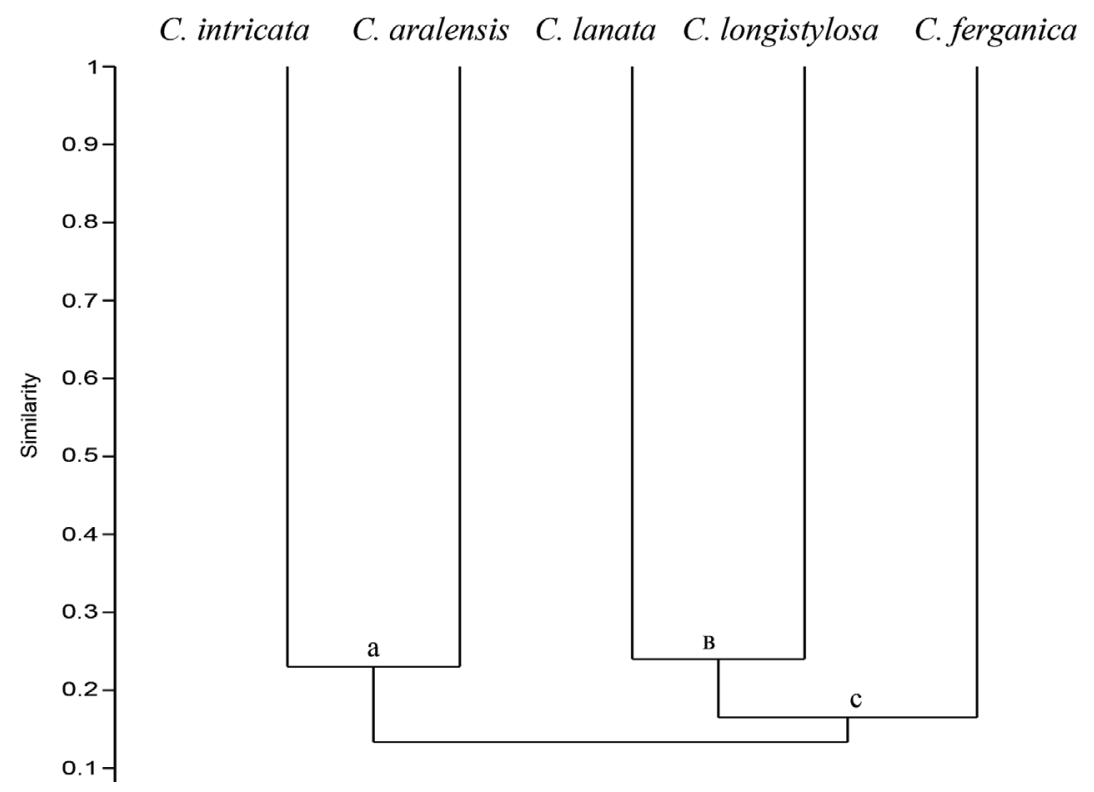

Fig. 4. Cluster analysis by Jaccard similarity coefficient (Kj) in Climacoptera species by quantitative measurements of leaves. Abbreviations: $\mathrm{a}=$ Section Amblyostegia Pratov.; $\mathrm{b}=\mathrm{Sec}-$ tion Climacoptera Pratov.; c = Section Ulotricha Pratov

compared with $C$. intricata and C. longistylosa can be explained by their greater plasticity under wider area conditions. The species $C$. intricata, C. aralensis (endemic in Central Asia), and C. longistylosa (Central Asia, Afghanistan) were formed later under arid climate conditions in a narrower ecological range.

Acknowledgements - I thank Dr Klaus-J. Appenroth, University of Jena, Germany, and Dr Áron Keresztes, Eötvös Loránd University, Budapest, Hungary, for critical discussions and correcting the language.

\section{REFERENCES}

Akhani, H. and Ghasemkhani, M. (2007): Diversity of photosynthetic organs in Chenopodiaceae from Golestan National Park (NE Iran) based on carbon isotope composition and anatomy of leaves and cotyledons. - Nova Hedwigia, Beih. 131: 265-277.

Atakhanov, B. O. and Bil, K. Ya. (1990): Comparative evaluation of distribution of $\mathrm{C}_{3}$ and $\mathrm{C}_{4}$ species in different seasons of vegetation of flora in the Karakum desert. - Problems of Desert Development 5: 30-36.

Barykina, R. P. and Chubatova, N. V. (2005): Big practicum of botany. Ecological anatomy of floral plants. - Tov-vo nauch. izd., Moscow, 77 pp. 
Butnik, A. A. (1995): Adapting strategies of woody and semiwoody plants in the arid environment (xerophyllization problem). - J. Arid Land Studies 5: 73-76.

Butnik, A. A. and Timchenko, O. V. (1987): Structure epidermis types of genus Chenopodiaceae. - Bot. Zhurnal 8(72): 1021-1030.

Butnik, A. A., Ashurmetov, O. A., Nigmanova, R. N. and Begbayev, G. F. (2009): Ecological anatomy of desert plants of Central Asia (Grass). - Fan, Tashkent, Vol. 3, 155 pp.

Carolin, R. C., Jacobs, S. W. L. and Vesk, M. (1975): Leaf structure in Chenopodiaceae. - J. Bot. Jahrb. Syst. 95: 226-255.

Dospekhov, B. A. (1979): The methodical of field experiment (with bases of statistical processing of results of researches). - Kolos, Moscow, $416 \mathrm{pp}$.

Inamdar, I. A., Gangadarnara, M., Morge, P. G. and Patel, R. M. (1977): Epidermal structure and ontogeny of stomata in some Centrospermae. - Feddes Repert. 88: 465-475.

Gamalei, Y. V. and Shirevdamba, T. (1988): The structure of plants of Trans-Altai Gobi. - In: Gamalei, Y. V., Gunin, P. D., Kamelin, R. V. and Slemnev, N. N. (eds): Deserts of Trans-Altai Gobi: characteristic of dominant plants. Nauka, Leningrad, pp. 44-106.

Kadereit, G., Borsch, T., Weising, K. and Freitag, H. (2003): Phylogeny of Amaranthaceae and Chenopodiaceae and the evolution of $\mathrm{C}_{4}$ photosynthesis. - Int. J. Plant Sci. 164: 959-986. doi: 10.1086/378649

Korovin, E. P. (1958): Biological forms and the need for water plant species in arid zone. Trudy SAGU, Tashkent, 136: 79-96.

Lyubimov, V. Yu., Atakhanov, B. O. and Beale, K. Ya. (1986): Adaptation of the photosynthetic device of plants of the Kara Kum Desert to extreme conditions. - Physiol. of plants, Moscow, 5(33): 888-895.

Oppenheimer, H. R. (1960): Adaptation to drought, xerophytism. - Plant-water relationships in arid and semiarid conditions, Paris, 15: 105-138.

P'yankov, V. J., Vosnesenskaya, E. V. and Alexander, N. (2000): Occurrence of $C_{3}$ and $C_{4}$ photosynthesis in cotyledons and leaves of Salsola species (Chenopodiaceae). - Photosynth. Res. 63: 69-84.

P'yankov, V. I., Kuzmin, A. N., Demidov, E. D. and Maslov, A. I. (1992): Variety of biochemical pathways of $\mathrm{CO}_{2}$ fixation in plants genus Poaceae and Chenopodiaceae arid zone of Central Asia. - Plant Physiol., Moscow, 4(39): 21-29.

P’yankov, V. J, Kuzmin, A., Ku, M., Black, C., Artyusheva, E. and Eduvard, Y. (1998): Diversity of Kranz-anatomy and biochemical types of $\mathrm{CO}_{2}$ fixation in leaves and cotyledons among Chenopodiaceae. - Photosynth. Mech. Effect 5: 4097-4100.

Schmidt, V. M. (1984): Mathematical methods of botany. - Leningrad State Univ. Press, Leningrad, $288 \mathrm{pp}$.

Seddon, G. (1974): Xerophytes, xeromorphus and sclerophylls: the history of some concepts in ecology. - Biol. J. Linn. Soc. 1(6): 65-87.

Stocker, O. (1960): Physiological and morphological changes in plants due to water deficiency. Plant-water relationships in arid and semiarid conditions. UNESCO, Paris, 15: 63-104.

Sundberg, M. D. (1986): A comparison of stomata distribution and length in succulent and non-succulent desert plants. - Phytomorphologie 1-2(36): 53-66.

Voznesenskaya, E. V., Franceschi, V. R., Pyankov, V. I. and Edwards, G. E. (1999): Anatomy, chloroplast structure and compartmentation of enzymes relative to photosynthetic mechanisms in leaves and cotyledons of species in the tribe Salsoleae (Chenopodiaceae). - J. Exp. Bot. 341: 1779-1795.

Zakharevich, S. F. (1954): Methodical of the description of epidermis of a leaf. - Vestnik LGU, Leningrad. 4: 65-75. 